\title{
JULIÁN MEZA
}

Jean Meyer*

Julián, siempre quedé en deuda contigo, por el apoyo incondicional que me diste en aquellos años lejanos, olvidados ya, cuando el "revisionismo" era un pecado mortal en México, cuando uno tocaba a la sacrosanta "Revolución Mexicana", en México, y en otras partes cuando tocaba la URSS, el castrismo, el sandinismo y demás. Luego de abogado te convertiste en propagandista mío y me llevabas con tus jóvenes estudiantes entusiastas. Entusiastas, porque su maestro, tú, mi querido Julián, los ha entusiasmado siempre, cuando habla de historia, de filosofía política o de literatura.

Los que te leen, los que te conocen personalmente, aprecian tu temperamento cálido (me gusta la palabra francesa : "chaleureux"), expansivo, tu gusto por la tertulia, la buena mesa y el vino. Tú concibes la filosofía política como un compromiso, en defensa de una fe razonable en la posibilidad de una democracia justa, una fe razonable en las pobres libertades calumniadas como "burguesas". Eso tuvo su mérito en los años mexicanos 1970-2000, cuando no se perdonaba el pecado "contrarrevolucionario" de denunciar las dictaduras "revolucionarias" o de ponderar los méritos de nuestra mexicana y "suspendida" o "traicionada" revolufia. El Che Guevara no fue nunca tu ídolo.

Reconocer la posibilidad democrática es algo que compartes con los que fueron tus maestros antes de volverse tus amigos queridos y

* Historiador. Investigador del Centro de Investigación y Docencia Económicas, A.C. 
querendones (me consta), François Furet y Edgar Morin, en la línea de Tocqueville, Raymond Aron, Octavio Paz. Muchos franceses ¿no? Es que Francia pesa mucho en tu vida. Después de los años de estudios en la École Pratique que ahora se llama École des Hautes Études, vinieron los años sabáticos, cuando te invitaban, y te invitan precisamente aquellos maestros y amigos franceses. Ahí está tu familiaridad con la historia, la filosofía política, la literatura francesa.

¡Ah, la literatura! Confieso que tu obra novelesca es para mí la face cachée de la lune, la que no conozco, la que en algún año sabático espero leer, digo espero porque los sabáticos ya no son lo que idearon sus inventores. Así que hasta ahora soy manco o hemipléjico frente a tu obra. Eso sí, míos son tus ensayos, críticas, reseñas, conversaciones, entrevistas, libros de filosofía e historia. Hasta leí, hace mil años, un largo texto tuyo -creo que sigue inédito-sobre las guerras diferentes que hicieron mexicas y españoles cuando se toparon.

Estuviste en todos los combates políticos de nuestra generación, ya lo dije, siempre en el bando de la libertad, de las libertades. Tu fe en la posibilidad de una buena democracia ha formado tu actitud frente al mundo como un todo, al mundo social y a nuestro lugar en él, a corto y largo plazo, en el pasado y el presente, hacia el futuro. Por esos tus alumnos del ITAM, generación tras generación, despiertan a tu voz, porque eres un hombre de convicción y de palabra.

Me has entrevistado, no te entrevisté nunca, pero puedo imaginarte diciendo que la ética, base de la verdadera filosofía política, se funda en el reconocimiento de la realidad independiente y de la importancia fundamental de la persona y de la comunidad. Ni individualismo vibriónico y egoísta, ni comunismo nivelador, ni masa anónima o lonely crowd, sino relaciones apropiadas entre personas, cada una siendo única; tales relaciones personales forman un nexo, de modo que nuestra relación con una persona repercuta en nuestra relación con los otros.

Tu manera de vivir tus relaciones personales explica por qué tienes tantos amigos sinceros, porque los conservas, con todo y largas ausencias por ambas partes. Contigo deja de ser cierto el dicho "ojos que no ven, corazón que no siente", loin des yeux, loin du coeur, y soy testi- 
go de la amistad que te tenía el demasiado temprano desaparecido Furet, de la amistad cariñosa y paternal que te tiene Morin, el prodigioso Morin...

Para ti, el mundo tiene que ser comuna, comunidad, creación permanente, continua (y frágil) en la cual todos somos creadores y creados. Tu lema es el de los tres mosqueteros Un pour tous et tous pour un... Sabes perfectamente que las relaciones personales son positivas y negativas, que incluyen odio y envidia,vanidad y mezquindad, mientras que tú cultivas generosidad, bonhomía y bohemia. Te das a querer y te queremos, te quieren. Tanto en tu salón de clase, como en la comunidad intelectual y literaria. En tu forma de establecer relaciones interpersonales, la palabra clave es "comunidad".

Nunca hablamos de religión, de metafísica, pero sí de lo justo, de lo bueno, de la Justicia, no de manera abstracta, sino entre las personas y las comunidades de todo tipo, micro y macro, en términos no de categóricos absolutos, sino de cooperación entre libres e iguales. Lo bueno, lo deseable es nuestra capacidad amistosa para vivir en comunidad; lo malo, que deforma nuestra esencia personal, es lo que destruye la comunidad o impide su construcción. Nuestra apertura a los otros, así lo vives tú, es el único remedio a la terrible soledad que amenaza cuando triunfa el mal; el Malo, dicen los cristianos ortodoxos al final del Padre Nuestro, porque el mal es una persona, un espíritu, brillante por cierto.

$A$ deviant case, eso eres en la comunidad académica, porque no se te puede catalogar, porque lo sabes todo y escribes de todo, sobre todo, hasta hermosos libros de viajes, todos dedicados al Mediterráneo, Sicilia, Constantinopla, tan querida por tu muy querido Álvaro Mutis, y ahora Cerdeña... el mar, tres veces.

"Ningún género me es extranjero", podrías decir con orgullo, si orgulloso fueras. Como no es el caso, déjame decirlo a tus lectores amigos.

Un abrazo, mi querido Julián, de tu Juan. 
La reproducción total o parcial de este artículo se podrá hacer si el ITAM otorga la autorización previamente por escrito. 